\title{
Energy Management for Fuel Cell/Battery Hybrid Unmanned Aerial Vehicle
}

\author{
Zhibo Cheng, Huiying Liu, Peiran Yu, Lin Zhu, Tianhao Sun, Yongming Yao* \\ School of Mechanical and Aerospace Engineering, Jilin University, 130025 Changchun, China \\ *E-mail: ymyao@jlu.edu.cn
}

Received: 9 May 2021 / Accepted: 28 June 2021 / Published: 10 August 2021

\begin{abstract}
The poor endurance of battery-powered unmanned aerial vehicles (UAVs) can be improved by applying a fuel cell hybrid system. Energy management can significantly affect the hybrid system performance. Energy management in fuel cell/battery hybrid fixed-wing UAVs is challenged by the variable flight conditions of the UAVs and the complex energy flows in the hybrid system. This study first establishes a mathematical model of the fuel cell/battery hybrid fixed-wing UAV. Next, four energy management strategies (EMSs), namely fuzzy logic, dynamic programming, Pontryagin's minimum principle (PMP), and improved PMP, are proposed. The improved PMP-based EMS considers the fuel cell current and the power changing rate. The simulation results based on the actual working load of a fixed-wing UAV in the MATLAB environment show that the proposed EMSs are effective in extending the UAV endurance while reducing the change rate of the fuel cell output power and improving adverse effects on the battery lifetime. The methodologies presented herein can be applied to other UAVs and hybrid systems.
\end{abstract}

Keywords: fuel cell; hybrid system; energy management; unmanned aerial vehicle; Pontryagin's minimum principle.

\section{$\underline{\text { FULL TEXT }}$}

(C) 2021 The Authors. Published by ESG (www.electrochemsci.org). This article is an open access article distributed under the terms and conditions of the Creative Commons Attribution license (http://creativecommons.org/licenses/by/4.0/). 